\title{
PUTTING THE LEADER BACK INTO AUTHENTIC LEADERSHIP: RECONCEPTUALISING AND RETHINKING LEADERS.
}

\begin{abstract}
Increasingly poor and unethical decision making on the part of leaders across the globe, such as the recent Australian Cricket ball tampering scandal, is a significant challenge for society and for organisations. Authentic leadership development is one strategy that has been positioned as an antidote to unethical leadership behaviours. However, despite growing interest in authentic leadership, the construct still embodies several criticisms including conceptual clarity, leader centricity, bias towards the person, not the leader, philosophical ambiguity, and demographic challenges. Each of these criticisms will be explored in depth to inform a reconceptualisation of the authentic leader construct, comprising indicators of awareness, sincerity, balanced processing, positive moral perspective, and informal influence. Importantly, this revised conceptualisation considers how researchers can conceptually distinguish between authentic leaders, followers, and individuals. To conclude, we propose a research agenda for authentic leaders, encouraging the pursuit of further construct clarity, including the development of rigorous authentic leader behaviour measures, expanding the psychometric profile of the authentic leader construct, increasing the focus on authentic followers, and enhancing leader development programs.
\end{abstract}

\section{Keywords}

Authentic leadership, authenticity, leadership, construct clarity, definition of leadership.

\section{JEL Code}

M12. Business Administration and Business Economics > Business Administration > Personnel Management, Executives, and Executive Compensation. 
Ethical crises abound. Bad and unethical decisions from some of the most prominent political, societal, and organisational leaders offer a global challenge for contemporary thinkers. Examples can be seen daily in both global and local media. Recent Australian examples include the 'turncoat' move of Tasmanian House of Representative Speaker Sue Hickey, who opted to vote against her party's nomination for Speaker, and instead dealt with the cross-bench to gain sufficient votes for the more senior parliamentary position (Burgess, 2018).

Or, the March 2018, The Australian cricket team 'sandpaper' scandal is another example, where the former captain Steve Smith, former vice-captain David Warner, and junior player Cameron Bancroft, tampered with the game ball to gain a competitive advantage (Buckingham-Jones, 2018). This case of unethical behaviour was reignited only months later when another team captain, Dinesh Chandimal, of the Sri Lankan cricket team, was also found guilty for ball tampering in June 2018 (Lalor, 2018). Importantly, is the recognition of the role that leaders play in enabling such unethical climates to exist. An independent report commissioned by Cricket Australia determined the organisation and its leadership were partly to blame for ball tampering (The Ethics Centre, 2018), and led to the Chairperson's resignation shortly after (BBC, 2018). Authentic leadership has been linked to positive outcomes (e.g. trust, engagement, and commitment) in similar sporting organisations (Bandura \& Kavussanu, 2018; McDowell, Huang, \& Caza, 2018).

These practical examples are just some of many in the growing trend of leaders acting unethically for their own personal gain (e.g. Amir, Kallunki, \& Nilsson, 2014; Bird, Momente, \& Reggiani, 2012; Capezio \& Mavisakalyan, 2016; Grace, 2006; Marsh, 1996). Now, more than ever, there is a need for research into positive styles of leadership that respond to these challenges (Crawford, Dawkins, Martin, \& Lewis, 2017). The importance of this work stems from a genuine aim to generate solutions to stem the emergence of such 
ethical challenges. By better understanding authentic leaders, scholars and practitioners can better understand the development of authentic leadership. Through enhanced authentic leadership development, the challenges of unethical leadership can be stemmed in those that undergo such training. Reduced unethical leadership practice can result in more flourishing organisations and people (Luthans \& Avolio, 2003). Our work begins with ensuring a better understanding of authentic leaders.

One such group posited to have the strength of character to positively address societal and organisational challenges are authentic leaders (Gardner, Cogliser, Davis, \& Dickens, 2011; Luthans \& Avolio, 2003). Researchers have, however, found conceptual confusion between the four domains of authentic leadership (Crawford, Lewis, Martin, \& Dawkins, 2017), specifically, the authentic leader (actor), authentic leadership (an influencing process between two or more actors), authentic followership (a process of engaging with, and responding to, influencing), and the authentic follower (actor). Despite widespread attention, the construct itself has not achieved maturity and it embodies criticism related to its conceptualisation and measurement (Iszatt-White \& Kempster, 2018).

An unstable conceptual framework limits full understanding of authentic leaders and reduces theoretical application to practice (e.g. leader development programs). In this paper, we outline three of our criticisms with the current conceptualisations of authentic leaders, including the lack of conceptual clarity; the leader-centricity; and an overemphasis on the authentic person, not the authentic leader. In addition, we synthesise some of the existing critique of authentic leaders: the roots of authenticity, its morality, and demographic challenges. We then begin to address each of these by proposing a redeveloped authentic leader construct, which provides a clearer and more parsimonious theory. To do this, we draw on the extant literature in the field of authenticity, authentic leadership, and organisational 
behaviour more broadly. Finally, we outline the theoretical and practical implications of our proposed reconceptualisation, along with directions for future research.

\section{A CRITICAL REVIEW OF AUTHENTIC LEADERSHIP}

\subsection{Nomenclature}

Before entering into a critical analysis and review focussed on authentic leaders, it is important to acknowledge that there is conflict surrounding the term 'authentic leadership'. Many existing conceptualisations use authentic leadership and authentic leaders interchangeably (e.g. Walumbwa et al., 2008; Neider \& Schriesheim 2011). However, explicit acknowledgement of what authentic leader behaviours actually comprise appears to have been neglected in the literature, with researchers typically only highlighting the individual characteristics of an authentic leader and considering that as 'authentic leadership', and confusing the two domains (leader and leadership: e.g. Walumbwa et al., 2008). To clarify, the authentic leader characteristics (i.e. the person) are different to authentic leadership (i.e. the process). It is likely though, that the characteristics of the authentic leader in context with the significant other (e.g. follower) and environment will affect and create the process of leadership (Grant-Smith \& Colley, 2018; Stewart et al., 2017). Similar to Hu and Liden's (2013) relative-leader member exchange model, leaders enact leadership in different ways depending on their present circumstance and the availability of external information.

\subsection{Existing definitions}

Whilst several conceptualisations of authentic leadership have been proposed and evaluated in empirical research (see Gardner et al., (2011), arguably the most commonly used definition (2,169 citations, Google Scholar, July 2018) and subsequently the definition we focus on in this paper, is provided below.

A pattern of leader behaviour that draws upon and promotes both positive psychological capacities and a positive ethical climate, to foster greater self- 
awareness, an internalised moral perspective, balanced processing of information, and relational transparency on the part of leaders working with followers, fostering positive self-development (Walumbwa et al., 2008, p. 94).

In this definition, the construct of authentic leadership is multidimensional, comprising four dimensions: self-awareness, internalised moral perspective, relational transparency, and balanced processing. Self-awareness is the demonstrated understanding of how one derives and makes meaning of the world, an understanding of their true self and how that process impacts self-perceptions and others. Internalised moral perspective is an internalised and integrated form of self-regulation guided by internal moral standards and values versus group, organisational, and societal pressures, decision making and behaviour consistent with these internalised values. Relational transparency is presenting one's authentic self openly and free of distortion to others, and balanced processing is objectively analysing all relevant data before coming to a decision.

The confusing element is that Walumbwa and colleagues' (2008) definition appears to define authentic leadership (e.g. the process) but conceptualises a model of authentic leaders (e.g. the person). To date, critical evaluation of this conceptualisation has been lacking. Authentic leadership, in its initial positioning, was considered as a multilevel theory (Day et al., 2014). Meaning that it was contextualised within layers and hierarchies (e.g. leaders, followers, superiors, subordinates, and peers), specifically within a leader-follower dyad, and with leaders in groups, and organisations. Yet, within the literature, we still do not know exactly what each of the levels look like, or, for example, how followers differ from workers or subordinates (Learmonth \& Morrell, 2016). Therefore, in this paper, we aim to advance understanding of one level of the authentic leadership model, the authentic leader.

One of the recommendations from Gardner et al. (2011) in their review of authentic leadership was the need for stronger theory development of the authentic leadership process. 
This point was reiterated by Antonakis (2017) in relation to the entire leadership discipline. In particular, Gardner et al. (2011) suggested that theory development is needed from perspectives other than positivist, with 93 percent of authentic leadership theory publications using a positivist approach, compared to interpretive (7\%) and critical (0\%) approaches.

Gardner et al. (2011), also argued that there are mixed degrees of rigor in the purely theoretical authentic leadership papers. As such, we aim to address some of the primary criticism of the authentic leader conceptualisation, and so we begin with the first limitation of construct clarity.

\section{CRITIQUE OF AUTHENTIC LEADERSHIP}

Since its inception, authentic leadership has been widely critiqued and debated. In the following section, we seek to consolidate and recognise the most common criticisms, prior to continuing with a reconceptualisation of the authentic leader that addresses such criticism. A lack of construct clarity is the first critique we outline, followed by a discussion of the leadercentricity of existing models, the ambiguity between authentic individuals and authentic leaders, and the acknowledgment of a flawed foundations of authenticity. We also recognise existing critiques of the ethical underpinnings of authentic leadership, and the challenges associated with demographic minorities (e.g. gender, ethnicity, and sexuality) enacting authentic leadership.

\subsection{Construct clarity}

The authentic leadership construct comprises ambiguity, and lacks construct clarity and theoretical rigor, like many existing management theories (Antonakis, 2017; Locke 2012; Posdakoff et al., 2016). Construct clarity is achieved when a construct is translated into a coherent and concise definition, with parsimonious distinctions between what it is, and what it is not (Bacharach, 1989; Podsakoff et al., 2016; Suddaby, 2010). One of the most 
prominent aspects of the ambiguity concerning authentic leadership is its definition via its nomological network (e.g. positive psychological capacities and a positive ethical climate), rather than being positioned as an independent construct. Another aspect of ambiguity is the empirical redundancy established between authentic and transformational leadership (Banks et al., 2016). Suddaby (2010) suggests scholars respond to construct clarity issues by developing conceptually clear construct definitions. These criteria include: i) to provide precise definitions with parsimonious categorical distinctions; ii) to delineate the scope conditions and contextual circumstances where the construct will or will not apply; iii) to present semantic relationships with related constructs; and iv) to demonstrate coherence and logical consistency. By adopting these criteria, we distinguish authentic leaders from the authentic leadership process, the authentic individual, and even authentic followers.

\subsection{Leader-centricity}

In leadership, there are four domains: the leader; follower; leadership, and followership (Crawford et al., 2018; Graen \& Uhl-Bien, 1995; Liu, 2017). Authentic leadership scholars have mostly focused on the leader and leadership, with ambiguity between the two. Despite the emergence of authentic followership literature in recent years (e.g. Avolio \& Reichard, 2008; de Zilwa et al., 2014), much of this research has focused on authentic followership as an extension of authentic leadership, rather than examining authentic followership as an independent construct worthy of pursuit in, and of, itself (Crawford et al., 2018). Moreover, there has been scant attention given to the conceptual distinction between authentic leaders and followers, or how the processes of followership and leadership differ. Ford and Harding (2018) highlighted that leadership theories are underpinned by a desire for power over the 'follower' masses, despite that they ought to treat these individuals in their own right (Crawford et al., 2018; de Zilwa et al., 2014). In building on these domains and Kabalo's (2015) leader-follower interrelations model, the authentic leader-follower relationship (Figure 
1), comprises the authentic leader, a top-down influencing process (authentic leadership), a bottom-up influencing process (authentic followership), and the authentic follower. The focus of this paper begins with the authentic leader.

\section{INSERT FIGURE 1 ABOUT HERE}

\subsection{Ambiguity between an authentic individual and authentic leader}

Within the existing conceptualisations of authentic leadership, an authentic leader is commonly defined as the synergy of four behaviours: self-awareness, relational transparency, internalised moral perspective, and balanced processing. These four dimensions have also been used to describe an authentic person (Kernis \& Goldman, 2006); that is, an individual who makes autonomous decisions without consideration for what others think or do (Bogren, 2006). As such, an authentic leader must be an authentic individual (see Table 1), but the reverse is not necessarily true. An individual can have high degrees of authenticity, without necessarily having leadership capabilities. While it is reasonable to expect a degree of convergence in conceptually related constructs, constructs should be distinguishable at a conceptual level (Suddaby, 2010). Thus, the current conceptualisation of authentic leadership (i.e. that proposed by Walumbwa et al., 2008) does not reflect authentic leaders, as it fails to demonstrate substantial conceptual distinction between an authentic leader and an authentic person. Leaders (individuals with the ability to influence) and managers (individuals with formal authority) are not the same (Toor \& Ofori, 2008; Zaleznik, 2004). As such, an authentic person with a formal leadership role (e.g. a management role) does not always necessitate an authentic leader.

INSERT TABLE 1 ABOUT HERE

\subsection{Acknowledging authenticity foundations}


Another criticism of authentic leadership is the misspecification of authenticity. This is perhaps drawn out by the competing demands of complex authentic discourse (Tomkins \& Simpson, 2015), and desires for leaders to operate in complex environments (Chung, 2015). Whilst it is not possible to resolve this philosophical complexity as a subset of this paper, we do seek its acknowledgement. Leadership scholars posit the roots of leader authenticity as accurately expressing one's innermost feelings and cognitions (Van Dierendonck \& Nuijten, 2011); that authenticity is relational (Eagly, 2005); and self-referential (Avolio \& Gardner, 2005). This ambiguity has led to scholars questioning the impossibility of achieving true authenticity in authentic leadership (Ford \& Harding, 2011), and the problematisation of the construct in the context of immigrant women of colour (Ngunjiri \& Hernandez, 2017). The over-emphasis on pro-social, positive behaviour is also considered an inaccurate lens though which to view leader authenticity (Ladkin, Spiller, \& Craze, 2016). In response, our conceptualisation acknowledges positive and negative behaviour, as well as the conscious and unconscious components of self-referential authenticity (Ladkin et al., 2016). While authenticity is most likely shaped in intrapersonal and interpersonal relationships, it is the journey of individuation that offers the starting point to the reflexive nature of authentic leader behaviours.

\subsection{Moral component}

More recently, strong debate has emerged regarding the ethical and moral components of authentic leaders. Price (2017), for example, outlined the difficulties associated with locating leader ethics in normatively appropriate conduct. One attempt to explain authentic leader ethics has centred on distinguishing the construct from Machiavellianism (Rego, Lopes, \& Simpson, 2017; Sendjaya et al., 2016). For example, Rego et al., (2017) proposed a typology of leaders that comprised authentic, Machiavelically authentic, Machiavellian, and null leaders. Sendjaya et al. (2016) drew on cognitive moral development and moral identity 
theory to demonstrate that when Machiavellianism is high, a negative relationship exists between authentic leadership and moral actions. In a discursive analysis of authentic leaders' ethicality and effectiveness, Iszatt-White et al. (2018) argued that ethical leaders are praised when acting virtuously, but criticised when acting ineffectively. So, when leaders operate virtuously (e.g. breach no ethical rules) but do not act effectively (e.g. do not meet organisational goals), others may choose to praise the ethical behaviour or criticise the ineffective practice. Or praise effective practice despite it being unethical (e.g. Machiavellian leaders are often effective in organisational goals). Some may recognise the virtue in behaviour, and ineffective practice, yet the halo effect may make one more likely to be responded to than the other. These conflicting discourses result in leaders feeling pressure to act either ethically or effectively, not understand how they can operate in both.

We problematise such a dichotomy as a false-choice and suggest that a third available option is to process decisions in a balanced way and seek solutions that are both effective and ethical. The challenge, however, is that ethical decisions are sometimes less effective than unethical decisions. When leaders are evaluating the long-term outcomes of making socially responsible and ethical decisions, it is evident that there are significant positive outcomes (Mahoney \& Thorne, 2005). Yet, like all ethics, there are grey areas. For example, using members' schemes of arrangement to win corporate control resulting in lower shareholders receiving lower prices (Bugeja et al., 2016). Or, short-term incentives for executives resulting in less long-term investment and higher dividend payments than long-term incentives (Agha, 2015).

Collinson (2017) argues that while there is a sense of universality associated with authentic leadership, the construct lacks adequate definition of what it is to be ethical. For example, some scholars argue that by demonstrating 'high levels' of certain behaviours (e.g. 
integrity or courage) a leader is ethical (Avolio et al., 2004; Gardner, Fischer, \& Hunt, 2009; Walumbwa et al., 2008). Another possible solution to authentic leader behaviours, is the foundations of virtue ethics underpinning their behaviours (Wilson, 2014). That said, the criteria that underpins ethics in authentic leadership would be excellence of character (arête) linked to the agent's role (ergon), with the intention of promoting human flourishing. In contrast, many authentic leadership scholars (e.g. Gardner et al., 2011) adopt a consequentialist view of ethics (e.g. the leader/follower as a 'means to an end', with the end being corporate performance). Some view authentic leadership through a deontological lens and see authentic leader/followers as 'ends' in their own right (Wilson, 2014). We argue a virtue-ethics case, whereby human flourishing is the desired end, with excellence of character the means. The difficulty in this ethical application is the lack of consistency of what 'virtue' is (Newstead, Macklin, Dawkins, \& Martin, 2018). A recent conceptualisation of virtue (Newstead et al., 2018, n.p.) articulates the construct as "the human inclination to feel, think, and act in ways that express moral excellence and contribute to the common good". Moralised leadership also posits that leader ethics stems primarily from the moralisation of followers (Fehr, Yam, \& Dang, 2015). From this perspective of virtue, a leader's ethics can be understood through an internal self-assessment of character, combined with the moralised external assessment of the contribution to the good of those around them.

\subsection{Demographic critique}

The critique addressed in this paper is the applicability of authentic leadership theory across different demographics. Fine (2017), for example, highlights two key issues that prevent gender and sexual minorities from embodying and practicing authentic leadership. The first, unadulterated authenticity when the notion of the self is fundamentally different from the prevailing societal norms. And, the second, the presentation of authenticity can result 
complexity of comprehension. Liu et al., (2015) in an examination of two Australian bank CEOs during the GFC, found that individuals enacted authenticity in line with norms around their gender. Miller (2016) further exemplifies that sexuality and race minorities may face 'navigated oppression' (e.g. stereotyping, tokenisation, and exoticisation) as a result of seeking to enable the presentation of an authentic self. Previous research has found that leaders who are indigenous (Faircloth, 2017), female (Eagly, 2005; Fox-Kirk, 2017; Gardiner, 2015; Hopkins \& O’Neil, 2015), racial minorities (Jones, 2016), have cultural differences (Khilji, 2015), or have a disability (Procknow et al., 2017) experience some tension in practicing authentic leadership.

This leads us to theorise that the process of enabling leadership must stem from a strong need to separate leaders from leadership. Environmental and contextual factors and who a leader is leading (e.g. the type of follower) will dictate how leadership is enacted (Ali, 2015). This reiterates our earlier argument about the importance of theorising the authentic leader first, the authentic follower second, and authentic leadership third. Accordingly, in the next section we provide a reconceptualisation of the authentic leader.

\section{RECONCEPTUALISING THE AUTHENTIC LEADER}

In light of the criticisms presented in this paper, we suggest there is a need to re-evaluate the domains of the leader-follower relationship and understand how a leader and leadership are different. This, in turn, will provide a framework for the authentic leader/follower relationship, which clearly conceptualises the leader and follower roles and how these translate to leadership and followership, respectively. This will also enable clearer distinction between an authentic leader, an authentic follower, and an authentic person.

Given that there is substantial support for the existing four-dimensional model of authentic leaders (e.g. Neider \& Schriesheim 2011), we do not seek to 'reinvent the wheel,' 
but rather evaluate whether each dimension adequately describes the authentic leader from a theoretical perspective. In addition, we will propose an extension of the current model to include a fifth dimension (i.e. informal influence), which allows greater reflection of what authentic leaders actually do, regardless of their job roles and formal titles.

\subsection{Awareness}

Self-awareness is a state-like construct (Govern \& Marsh, 2001) key to an individual understanding their own self-concept, and knowing their 'true self'. In relation to authentic leaders, self-awareness is defined as understanding how one derives and makes meaning of the world, and how that process has an impact on their self-concept (Walumbwa et al., 2008). From this perspective, self-awareness relates to meaning generation, and the impact that one's worldview has on their self-concept.

Existing notions of self-awareness require significant philosophising about personal sense making (Walumbwa et al., 2008), which is only truly evident at the highest end of this construct. Yet, we argue that authentic leaders go beyond individual-level self-awareness. These individuals are aware of others (i.e. social awareness), just like an authentic individual (see Kernis \& Goldman, 2006). In emotional intelligence research, self-awareness is the ability to understand one's own feelings and make an accurate self-assessment (Gardner \& Stough, 2002). In the same stream, social-awareness is the ability to accurately assess an individual's surroundings (Gardner \& Stough, 2002). Both of these are manifestations of awareness in two contexts.

Although self-awareness encompasses knowing one's self in private and public contexts, it also includes situational variance and environmental awareness (Govern \& Marsh, 2001). This is particularly important for a leader; an individual who requires sufficient awareness of others' opinions and the context they are operating within. An 
authentic leader has an awareness of others (e.g. public awareness) and insight into the situational context (e.g. surrounding awareness), beyond that of themselves, like an authentic person would.

We posit that authentic leaders demonstrate awareness of themselves and others, beyond existing understandings of authentic leader behaviours. Thus, awareness contains two sub-dimensions: self-awareness (having insight into, and trusting, one's situational selfrelevant cognitions and how these affects their behaviours), and social awareness (having insight into the behaviours of individuals and groups). Thus, in an authentic leader, Awareness is having insight into the behaviours of one's self, other individuals, and groups.

\subsection{Sincerity}

A significant limitation within existing authentic leader models is the inherent nature and conflict of authenticity in multilevel contexts. For example, the relational behavioural dimension of authentic leaders is typically positioned as 'relational transparency'. In other words, the presentation of one's self through the transparent sharing of information and feelings with others (Avolio et al., 2009), not dissimilar to relational orientation in Kernis and Goldman (2006)'s model of authenticity (Table 1). However, we acknowledge authenticity as self-referential primarily 'true to self', posing a significant flaw to the two-way leader/follower relationship (Ibarra, 2015). Although interpersonal elements are incorporated into relational transparency (e.g. sincerity and openness), the current model of authentic leaders inconsistently reflects an individual in intrapersonal relationships.

Relational transparency holds that the individual person (i.e. the self) is the sole member by which this construct is understood; that to be relationally transparent is selfactualised and self-measured. This construct, whilst upholding the self-referential nature of authenticity, is problematic at best. Given the multilevel nature of leadership (Day et al., 
2014), we believe that individual-focused dimensions (such as relational transparency) are inappropriate for contemporary leadership theory. Leaders are accountable to more than just themselves (Gray, Harymawan, \& Nowland, 2016; Sheehan et al., 2016), as regular corporate turnover of CEOs (Cheung \& Jackson, 2013) and political leaders continues to demonstrate. For example, recent media positions Australian Prime Minister Malcolm Turnbull and Opposition Leader Bill Shorten as having their leadership roles at risk from failed connection to their party's authentic identity (McGregor, 2018).

This issue, however, is less problematic if the notions of an authentic leader and an authentic person are distinguished by their multilevel and self-referential natures. Thus, striving for authentic relationships between an authentic leader and follower/others requires consideration of an alternate construct; a construct not dissimilar to authenticity, but applicable to the multilevel context that leaders operate within: sincerity. Although some researchers have highlighted the differences between sincerity and authenticity (e.g. Ford \& Harding, 2011; Trilling, 1971), the dimensions of an authentic leader include implicit elements of sincerity, such as openness and honesty in relationships. We believe that the dimension of relational transparency closely links to openness to oneself, but fails to apply in interpersonal relationships.

Furthermore, Ford and Harding (2011) distinguish authenticity and sincerity, stating that authenticity is 'self-referential,' while sincerity requires the presence of an 'external other'. When leaders operate in a collective (Avolio et al., 2009), their relationships are characterised by consideration for the external other(s), going beyond their self-interests. In defining sincerity, Trilling (1971, p. 2) states that sincerity is the "congruence between avowal and actual feeling", or the extent to which one's outward expression aligns with their internalised self (Avolio \& Gardner, 2005). This contrasts with authenticity, which is not synonymous with genuineness, sincerity, and honesty (Lawler \& Ashman, 2012). The nature 
of authenticity does not explicitly require anything more than honesty in an intrapersonal relationship (i.e. relationship with the self). As such, we propose that the synergy between sincerity and authenticity more accurately reflects the reality of an authentic leader. Sincerity requires honesty and integrity in interpersonal relationships, which provides a logical theoretical underpinning for why authentic leaders are able to develop trust.

We propose that sincerity enables authentic leaders to expose their authenticity in interpersonal relationships. We believe this promotes stronger alignment between the authentic leader and organisational behaviour theory, and affirms the conceptualisation of an authentic leader as an individual who is ultimately true to self, and true to others. As such, we define the relational orientation of an authentic leader as sincerity.

Sincerity is presenting one's true self to others, honestly and openly in all relationships and with consideration for the context.

\subsection{Balanced processing}

In the original models of authentic leaders, 'unbiased processing', reflecting the objective processing of self-relevant information without distortion, exaggeration, or deliberate ignorance (Gardner et al., 2011). Given humans are not completely objective, rational, and unbiased information processors (Gardner et al., 2005), it was more aptly termed balanced processing to reflect the ability of individuals to "objectively analyse all relevant data before coming to a decision" (Walumbwa et al., 2008: 95). Although Walumbwa and colleagues (2008) redefined the notion of unbiased processing, humans were still seen as unbiased in their ability to assess information objectively. Unlike computer software, humans are inherently bias (O’Neill \& Liu, 2016; Tice \& Wallace, 2003). As is often a risk within new paradigms, such as positive organisational scholarship, this redefinition reflects conceptual rebranding, or 'old wine in new bottles' (Hackman, 2009), with no fundamental distinction offered between the underlying assumptions. 
Leaders are likely to take risks to remain loyal to their values (Kernis \& Goldman, 2006), and are therefore less predictable in ambiguous situations where information is missing (Hsu et al., 2005). Ambiguity and risk should not affect rational decision-making, yet it appears to (Hsu et al., 2005). Humans make choices between several alternatives on the basis of a subjective value placed on those alternatives (Rangel et al., 2008). Therefore, consideration of context is pertinent when defining how authentic leaders process information. They are not completely rational and objective in thought, and thus, any behavioural model should not be based on such a static assumption.

For this reason, we theorise that authentic leaders base their decisions on value-adding (the 'positive') to both themselves, and their collective. When making decisions, authentic leaders imperfectly consider their internal flaws, strengths, and biases (i.e. awareness). To this end, we define the ability of an authentic leader to process information in a balanced manner as:

Balanced processing is the tendency to consider all relevant information available, and using this to make decisions that benefit the collective (e.g. followers).

\subsection{Positive moral perspective}

In earlier authentic leader models, internalised moral perspective is considered the moral component, or "being guided by internal moral standards, which are used to self-regulate one's behaviour" (Avolio et al., 2009, p. 424). For example, Neider and Schriesheim (2011) suggested that authentic leaders are guided internally, rather than by external pressures. Although this argument holds true for an authentic person, it fails to consider the deep nested nature of leadership, which should emphasise not only individual characteristics, but also surrounding stakeholders (Avolio et al., 2009).

We draw on virtue and moral identity theory (Zhu et al., 2011) to consider an alternative conceptualisation of the moral dimension of authentic leaders. Trait-like moral 
identity is a commitment to one's self to align with actions that promote, or protect the welfare of others (Hart \& Carlo, 2005). Virtue is defined as excellence of character and contributing to the common good. (Newstead et al., 2018, n.p.). An internalised moral perspective is similar to both of these, except it neglects the authentic leader's desire to also promote the welfare of others and contribute to the common good.

In their critique of authentic leaders, Ford and Harding (2011) argue that the construct commits a 'crime' by assuming a follower's individual sense of self can be reduced to that of an 'organisational cog'. In essence, the sense of self of followers is considered subsidiary to the sense of self of leaders; with followers 'mimicking' their leader's self-identity. We address this concern by adopting an alternate moral dimension, and posit that authentic leader theory should place a strong emphasis on developing one's own positive moral perspective, and using that to guide decision making.

The construct of moral identity aims to capture the degree to which an individual wants to be a moral person (Hart \& Carlo, 2005), and this does not quite capture the role of this dimension but provides important insight. Considering both the existing and inapt internalised moral perspective and moral identity, along with virtue-roots, we begin with moral perspective; one that comprises a deep-rooted understanding of ones' own moral framework. Yet, we go beyond this to incorporate the common good.

At their core, authentic leaders develop and promote more effective and empowered followers as emergent leaders (Gardner et al., 2005). These followers, ought to be developed and groomed into positive forms of leadership, rather than the alternative. We therefore consider this dimension to be a positive moral perspective; reframing the approach to ethical behaviour from an authentic leader's perspective. The key point of difference is not a complete shakeup of theory, but rather better alignment of the conceptualisation of authentic leaders with the actual practice of leadership. Thus, we consider the fourth dimension of the 
authentic leader to comprise two elements: a commitment to ones' own ethical framework, and an outward orientation, similar to moral identity and virtue, but remaining malleable as the moral behaviour of the leader is likely to be (Hannah, Lester, \& Vogelgesang, 2005).

There is a further challenge related to a leader's positive moral perspective that we seek to address. Through considering stakeholders and others in the leadership process, an authentic leader faces the potential for conflicts of interest (e.g. a CEO managing competing interests between shareholders and employees). An authentic leader, would process these conflicting interests carefully (i.e. balanced processing), and use a win-win approach to facilitate the competing interests within their collectives, without prioritising the needs of one party over the other. Additionally, their transparent and honest explanation (i.e. sincerity) enables an effective leader response (Agote et al., 2015). We argue that an authentic leader with a positive moral perspective processes the interests from the collective (i.e. balanced processing) and facilitates those that are most beneficial to the overall collective. Therefore, we redefine the positive moral perspective dimension in light of the criticism of morality unchallenged by the social and environmental circumstances leaders face. That is,

Positive moral perspective is the commitment to one's intrinsic ethical framework, and a willingness to subdue personal interests and ego to facilitate collective interests.

\subsection{Informal influence}

In addressing the third shortcoming of distinguishing between the authentic leader, authentic individual, and authentic follower, we suggest that the authentic leader construct include leadership influence. In doing so, we do not suggest that an authentic leader is not an authentic person, but rather an authentic person may not always be an authentic leader. Therefore, a dimension oriented around influence will better capture the authentic leader, and 
enable conceptual distinction between authentic leaders and authentic followers (see Figure 2).

In terms of defining leadership, definitions are abundant. In an attempt to consolidate key leadership definitions, Yukl (2013, p. 23) broadly defined leadership as:

The process of influencing others to understand and agree about what needs to be done and how to do it, and the process of facilitating individual and collective efforts to accomplish shared objectives.

One of the critical elements of leadership is the ability to influence others to achieve shared objectives. At present, the model of authentic leaders (Walumbwa et al., 2008) does not capture this dimension of influence. Leadership research has aimed to identify leader behaviours that most effectively enable this process of influence. The first four dimensions (i.e. awareness, sincerity, balanced processing, and a positive moral perspective) of an authentic leader are important elements for enabling the influencing process. However, an explicitly defined element of influencing shared goal attainment is missing from the Walumbwa et al. (2008) model.

Distinguishing between informal and formal influence is important. Most leadership studies focus on 'leaders' in management roles, assuming the role of a leader and a manager to be synonymous. Arguably, this is not the case, as authentic leaders can exist outside of a formal management role or situation. Kellerman (2012) distinguishes influence, power, and authority, beginning by arguing that power is the capacity of one individual (e.g. leader) to get another (e.g. follower/other) to do whatever the leader wants; with force if necessary. Kellerman (2012) also states that influence is the capacity to get someone else to do a desired action, but making them want to do it of their own volition. Finally, authority is the ability to make another do something using status, rank or position as the basis.

INSERT FIGURE 2 ABOUT HERE 
Twentieth century leadership theories typically focused on the authority element, with Great Man theory emphasising the need to find great people, put them in senior positions and obey them (Carlyle, 1993). Yet, transformational leaders are more about inspiring individuals to do particular tasks of their own volition: idealised influence (Burns, 1978).

Transformational leaders embody the behaviours that their followers desire, and encourage the adoption of new values and beliefs (LeBrasseur, Whissell, \& Ojha, 2002). Authentic leaders, however, do not change who they inherently are.

Two central distinctions of influence exist: formal and informal. Authentic leaders exist in both formal and informal leadership roles. However, in formal leadership roles, the authentic leader's informal influence enables them to transcend the abilities of other nonauthentic leaders with similar positions. The main difference between an authentic leader and a manager with formal authority is their informal influence; that is, the influence that exists in the absence of a formalised position. In recognition of an authentic leader's influence beyond that of an innately authentic individual or authentic follower, we propose a fifth authentic leader dimension. Thus:

Informal influence is the ability to inspire and motivate individuals to accomplish goals of their own volition, regardless of rank or position.

\subsection{A higher-order definition of the authentic leader}

Constructive critique paves the development of theoretically grounded definitions that provide greater conceptual clarity. In this paper, we have responded to the full range of criticisms of authentic leadership as identified in the literature, and reviewed the five dimensions that comprise our proposed model of authentic leaders. However, we are yet to propose an explicit definition of authentic leadership based on the synergies between the conceptual dimensions identified above. Essential to enabling rigorous authentic leadership research and practice is consensus regarding a succinct, theoretically informed definition of 
authentic leaders. Based on our review of extant authentic leadership literature and relevant theory we propose the following definition of the authentic leader:

An authentic leader influences and motivates followers to achieve goals through their sincerity and positive moral perspective, enabled through heightened awareness and balanced processing.

Drawing on this definition, the next step is to empirical test our reconceptualised model. Over time, longitudinal and/or cross-cultural research may find there are additional dimensions to authentic leaders, and thus researchers should remain open to such a possibility.

\subsection{Model specification}

Authentic leader behaviours we characterise as a multidimensional first-order reflective, second order-formative model. To go back a step, multidimensional constructs are primarily a reflective or aggregate model (Edwards, 2001; Law et al., 1998). These typically reflect the assumption that the construct is reflective at all levels or aggregate, that is formative at all levels (Diamantopoulous, Riefler, \& Roth, 2008). However, only considering these two options for model specification has resulted in measurement model misspecification (MacKenzie, Podsakoff, \& Jarvis, 2005). Two other options exist as there is a need in the leadership discipline to ensure that these are specified at each level: that is, reflective and formative at each level of the model.

Authentic leaders are often assumed to be a reflective construct (e.g. Walumbwa et al., 2008), because they are manifested by the synergy of four different, but interrelated firstorder dimensions. The overall construct of authentic leader behaviours is also more predictive than the four individual dimensions (Neider \& Schriesheim 2011). Whilst we agree that the model is multidimensional, we take issue with the specification of a reflective first and 
second order model. Using criteria for formative and reflective instruments (Coltman et al., 2008), we class the authentic leader behaviour model is more likely a first order reflective, second order formative.

To conclude the specification, we articulate the internal dimensional structure. That is, we believe there is a need to consider the dimensions in relation to a hierarchy, where relevant (Joseph \& Newman, 2010). Awareness and balanced processing (key foundations of authenticity) form the lowest level, as without awareness of self and ability to process information, the other dimensions are not possible. Sincerity (or the translation of one's true self, identified through high awareness) and positive moral perspectives (or a commitment to one's internal ethical framework, identified by awareness and enabled by balanced processing) form the second layer. The highest dimension is informal influence, because it is enabled and enhanced by a leader understanding themselves (awareness and balanced processing), and presenting that self (sincerity) and their positive moral perspectives to others.

\section{IMPLICATIONS AND FUTURE RESEARCH AGENDA}

Throughout this paper, we have discussed many of the flaws of authentic leadership, and proposed a reconceptualisation that responds to a number of these limitations, and of others (Iszatt-White \& Kempster, 2018). In theory, construct clarity enables better measurement and more valid empirical research, a pursuit we have commenced with this paper and in associated forthcoming empirical studies. From a practical perspective, confusion between the terms authentic leader and authentic leadership impedes understanding of what exactly leadership interventions are trying to develop: the person or the process? The clearer the construct, the easier it will be to know what intervention process to use. 
In addition, our definition of authentic leaders addresses criticisms of authentic leadership research. For example, an internalised moral perspective means an individual can theoretically score 'high' in testing, without being deemed by society to be a moral person. This has highlighted a fundamental flaw in the original conceptualisations of the internalised moral perspective dimension of Walumbwa et al.’s (2008) authentic leader model. To address this, we have redefined the moral underpinnings of authentic leaders to positive moral perspective as this newly defined dimension considers both a leader's own internalised moral perspective and the social welfare and perspectives of others.

\subsection{Defining the process of authentic leadership and followership}

Although this paper advances understanding of the authentic leader construct, authentic leadership and authentic followership still require consideration in future research. Future research needs to consider the authentic follower (see Crawford et al., 2018), and analyse how the two individuals (i.e. an authentic leader and an authentic follower) interact through the processes of authentic leadership and authentic followership. A holistic understanding of these four constructs will enable a working model to be established, from which others can learn how leaders and followers interact, how individuals can transition between leader and follower, and how to best develop these individuals. An extension of this is the importance of understanding the effectiveness of authentic leaders against longer serving leader models. Scholars could consider replicating nomological network studies from differing leadership theories. We outline four specific themes for future researchers in this area to consider when designing their research: measuring authentic leaders, risk of follower manipulation, application to diverse empirical contexts and a focus on development.

\subsection{Measuring authentic leaders}


When considering leadership theory, it is important that there is a clear trajectory into practice. In our analyses of the extant authentic leadership research, we were unable to identify an authentic leadership measure that would adequately distinguish an authentic leader from an authentic follower, authentic person, nor from an inauthentic leader, or inauthentic follower. Our revised model begins this pursuit, and we encourage future research efforts to continue this pursuit in both theoretical and empirical contexts. For example, given that three in four leadership development activities fail (Loew \& Wentworth, 2013) a priority for future research is the development of psychometrically-sound authentic leader measures, using best practice methods (Crawford \& Kelder, 2018). Such methods should include assessment of discriminant, convergent, and incremental validity, especially in relation to similar constructs (e.g. servant, spiritual, ethical, and transformational leadership).

To provide an example, our current working paper of ours is focused on more than 1,000 individuals surrounding the explication of a scale using best practice scale development methods, and empirically validating our assumptions in this paper. Importantly, future studies such as ours should consider seniority as a critical component in understanding influence, and indeed leader distance (e.g. Antonakis \& Atwater, 2002). A true leadership model should transcend seniority and be evident in Prime Ministers, CEOs, and front-line managers alike, but likely in different ways. We hope that other scholars will also take up the mantle in effectively assessing the construct clarity of our model empirically to enable the translation of authentic leader behaviours research to authentic leader development practice. For example, this has begun in Brisbane, Australia with qualitative exploration of the role of increased selfknowledge in developing authentic leader behaviours (Branson, 2007).

The development of a robust measure of authentic leaders will also enable measurement of authentic leaders across a variety of research contexts, including crosscultural and longitudinal studies. In particular, we encourage scholars to consider key areas 
where authentic leadership research has been critiqued for its lack of contextual understandings (e.g. within samples of gender, sexual, and ethnic minorities). We recognise that Gardner et al. (2011) commenced the collation and development of a nomological network of 'authentic leadership'. However, we suggest that their work may have confounded the nomological network of authenticity with authentic leadership, and suggest that some retesting may be required.

\subsection{The risk of follower manipulation}

Scholars of authentic leadership have a tendency to treat followers as individuals to be shaped by leaders (de Zilwa et al., 2014). We disagree with this notion, particularly given the fluid dynamic that can exist between authentic leaders and authentic followers (Crawford et al., 2018). Further in-depth and critical reviews of the literature and practice are needed in order to ascertain how followers are more than simply 'cogs' in an organisational system. For example, scholars should critically evaluate how an authentic leader can also be an authentic follower in a different context, and, how such a transitory lens can debunk the existing assumption that followers are secondary to the leader. We believe this process will properly begin when we consider assessing follower behaviours simultaneously to leaders.

\subsection{Application to diverse empirical contexts}

As highlighted in much of the authentic leadership critique, minority demographics have faced limited exploration in relation to how authentic leadership applies across gender, ethnicity, sexuality, and disabilities. Context dictates how a leader can lead (Ali, 2015), and such consideration to context and specific components of leaders and followers requires careful examination. The presentation of authentic selves is more challenging when such a self is equal to dominant societal norms or accepted conventions (Miles, 2016), and there are identified differences in the way two different cultures (Australia and Indonesia) present their 
authentic selves (Pekerti \& Sendjaya, 2010). Thus, it is crucial to consider how authentic leader behaviours apply, or do not apply in settings of immense diversity. One place many scholars begin is across the Eastern/Western philosophical divide (e.g. Walumbwa et al., 2008), and scholars should continue such examinations. However, of equal value is evaluating subcultures in Eastern and Western societies, and indeed subcultures of organisations. How does, for example, authentic leader behaviours apply in finance departments based on stringent tax and corporate governance rules compare to the same behaviours in a small business of five to ten employees? Small business is, and has been, a primary interest for Australian public policy (Davila et al., 2015; Holmes \& Zimmer, 1994) and presents an opportunity to deeply understand the contextual conditions of authentic leader environments.

\subsection{Focus on development}

We also echo the early commentary on authentic leadership, by purporting that authentic leadership development should be the key goal of conceptualising the theory (Luthans \& Avolio, 2003). Gardner et al., (2011) also argued for such continuation. To date, Avolio (2010) has championed much of the developmental component of the construct, but more research is required. That may include incorporating authentic leader behaviour principles into curricula, existing HR development and training programs, and subsequently, conducting extensive program evaluation. Incremental improvements in the development division of our field offer a real opportunity moving forward.

In conclusion, by critically reviewing the literature on authentic leaders and authentic leadership, this paper has identified a suite of criticisms within the existing models. Having discussed each of these criticisms in detail, we developed a revised theoretical model of authentic leaders. This model comprises five inter-related dimensions (awareness, sincerity, balanced processing, positive moral perspective, and informal influence), and has a strong 
emphasis on the newly proposed dimension of informal influence. Given that authentic leadership is an emerging field of study, this paper acts as a first step in the theoretical and conceptual refinement of the overarching construct. Through our reconceptualisation, future research can continue to establish authentic leadership's significance in management research and practice. 


\section{REFERENCES}

Agha, M (2016) Agency costs, executive incentives and corporate financial decisions. Australian Journal of Management, 41(3), 425-458.

Agote L, Aramburu N and Lines R (2015) Authentic Leadership Perception, Trust in the Leader, and Followers' Emotions in Organisational Change Processes. Journal of Applied Behavioural Science, 52(1): 35-63.

Ali, M (2016) Impact of gender-focused human resource management on performance: The mediating effects of gender diversity. Australian Journal of Management, 41(2), 376397.

Amir, E., Kallunki, J., and Nilsson, H (2014) Criminal convictions and risk taking. Australian Journal of Management, 39(4), 497-523.

Antonakis, J (2017) On doing better science: From thrill of discovery to policy implications. Leadership Quarterly. 28(1): 5-21.

Antonakis J and Atwater L (2002) Leader distance: A review and a proposed theory. Leadership Quarterly, 13(6): 673-704.

Aquino K and Reed II A (2002) The self-importance of moral identity. Journal of Personality and Social Psychology, 83(6): 1423.

Avolio, B (2010) Pursuing authentic leadership development. In: Nohria N and Khurana R (eds) The handbook of leadership theory and practice: A Harvard Business School centennial colloquium on advancing leadership. Boston, MA: Harvard Business School Press, pp. 739-768.

Avolio B and Gardner W (2005) Authentic leadership development: Getting to the root of positive forms of leadership. Leadership Quarterly, 16(3): 315-338. 
Avolio B and Reichard R (2008) The rise of authentic followership. In: Riggio R and Reichard R (eds) The art of followership: How great followers create great leaders and organisations. San Francisco, CA: Jossey-Bass, pp. 325-337.

Avolio B, Walumbwa F and Weber T (2009) Leadership: Current theories, research and future directions. Annual Review of Psychology, 60(1): 421-449.

Bacharach S (1989) Organisational theories: Some criteria for evaluation. Academy of Management Journal, 14(4): 496-515.

Bagozzi R, Youjae, Y \& Philips, L (1991) Assessing Construct Validity in Organisational Research. Administrative Science Quarterly, 36(3): 421-458.

Bandura C and Kavussanu M (2018) Authentic leadership in sport: Its relationship with athletes' enjoyment and commitment and the mediating role of autonomy and trust. International Journal of Sports Science \& Coaching, advanced online publication.

Banks G, McCauley K, Gardner W, \& Guler, C (2016) A meta-analytic review of authentic and transformational leadership: A test for redundancy. Leadership Quarterly, 27(4), 634-652.

BBC Sport (2018) Ball-tampering affair: Cricket Australia chairman David Peever resigns. BBC Sport, 1 November 2018.

Bird R, Momenté F \& Reggiani F (2012) The market acceptance of corporate social responsibility: a comparison across six countries/regions. Australian Journal of Management, 37(2), 153-168.

Bogren A (2006) The competent drinker, the authentic person and the strong person: Lines of reasoning in Swedish young people's discussions about alcohol. Journal of Youth Studies, 9(5): 515-538. 
Branson C (2007) Effects of structured self-reflection on the development of authentic leadership practices among Queensland primary school principals. Educational Management Administration \& Leadership, 35(2), 225-246.

Brown M and Mitchell M (2010) Ethical and unethical leadership: Exploring new avenues for future research. Business Ethics Quarterly, 20(4): 583-616.

Buckingham-Jones S (2018) Steve Smith 'cried for four days' after ball-tampering drama. The Australian. June 4, 2018.

Burns J (1978) Leadership. New York, NY: Harper and Row.

Burgess G (2018) New Speaker Sue Hickey distances herself from Liberal Party in dramatic first day of Parliament. ABC News. May 1, 2018.

Bugeja M, da Silva Rosa R, Izan H \& Ngan S (2016) To scheme or bid? Choice of takeover method and impact on premium. Australian Journal of Management, 41(2), 212-243.

Capezio A \& Mavisakalyan A (2016) Women in the boardroom and fraud: Evidence from Australia. Australian Journal of Management, 41(4), 719-734.

Carlyle T (1993) On heroes, hero-worship, and the heroic in history. Berkeley, CA: University of California Press.

Černe M, Dimovski V, Marič M, Penger S and Škerlavaj M (2014) Congruence of leader self-perceptions and follower perceptions of authentic leadership: Understanding what authentic leadership is and how it enhances employees' job satisfaction. Australian Journal of Management, 39(3): 453-471.

Collinson D, Smolović Jones O \& Grint K (2017) 'No More Heroes': Critical Perspectives on Leadership Romanticism. Organisation Studies, in-press. 
Chung Y (2017) The role of person-organisation fit and perceived organisational support in the relationship between workplace ostracism and behavioural outcomes. Australian Journal of Management, 42(2): 328-349.

Cheung W \& Jackson A (2013) Chief Executive Officer departures and market uncertainty. Australian Journal of Management, 38(2), 279-310.

Coltman T, Devinney T, Midgley D and Venaik S (2008) Formative versus reflective measurement models: Two applications of formative measurement. Journal of Business Research, 61(12): 1250-1262.

Crawford J, Dawkins S, Martin A, and Lewis G (2018) Conceptualising authentic followers and developing a future research agenda. In Cotter-Lockard D (eds) Authentic Leadership and Followership: International Perspectives. Cham, Switzerland: Palgrave MacMillan, pp. 271-293.

Crawford J, Dawkins S, Martin A, and Lewis, G (2017) Understanding the organisational climate of unethical leadership in the Australian Football League. Journal of Leadership Studies, 11(2): 52-54.

Crawford J and Kelder J-A (2018) Do we measure leadership effectively? Articulating and evaluating scale development psychometrics for best practice. Leadership Quarterly. Advanced online publication.

Davila A, Foster G, He X \& Shimizu C (2015) The rise and fall of startups: Creation and destruction of revenue and jobs by young companies. Australian Journal of Management, 40(1), 6-35.

Day D, Fleenor J, Atwater L, Sturm R and McKee R (2014) Advances in leader and leadership development: A review of 25 years of research and theory. Leadership Quarterly, 25(1): 63-82. 
de Zilwa D, Lapierre L and Carsten M (2014) A new conceptual framework for authentic followership. In: Laurent Lapierre M (eds) Followership: What is it, and why do people follow?. Bingley, UK: Emerald Group Publishing Ltd, pp. 47-72.

Diamantopoulos A, Riefler P and Roth K (2008) Advancing formative measurement models. Journal of Business Research, 61(12): 1203-1218.

Eagly A (2005) Achieving relational authenticity in leadership: Does gender matter? Leadership Quarterly, 16(3), 459-474.

Edwards J (2001) Multidimensional constructs in organisational behaviour research: An integrative analytical framework. Organisational Research Methods, 4(2): 144-192.

Faircloth S (2017) Reflections on the Concept of Authentic Leadership: From an Indigenous Scholar/Leader Perspective. Advances in Developing Human Resources, 19(4), 407419.

Fehr R, Yam K \& Dang C (2015). Moralized leadership: The construction and consequences of ethical leader perceptions. Academy of Management Review, 40(2), 182-209.

Fine L (2017) Gender and Sexual Minorities' Practice and Embodiment of Authentic Leadership: Challenges and Opportunities. Advances in Developing Human Resources, 19(4), 378-392.

Fox-Kirk W (2017) Viewing Authentic Leadership Through a Bourdieusian Lens: Understanding Gender and Leadership as Social Action. Advances in Developing Human Resources, 19(4), 439-453.

Ford J and Harding N (2011) The impossibility of the 'true self' of authentic leadership. Leadership, 7(4): 463-479.

Ford J \& Harding N (2018) Followers in leadership theory: Fiction, fantasy and illusion. Leadership, 14(1), 3-24. 
Gardiner R (2016) Gender, authenticity and leadership: Thinking with Arendt. Leadership, $12(5), 632-637$.

Gardner L and Stough C (2002). Examining the relationship between leadership and emotional intelligence in senior level managers. Leadership and Organisation Development Journal, 23(2): 68-78.

Gardner W, Avolio B, Luthans F, May D and Walumbwa F (2005) "Can you see the real me?" A self-based model of authentic leader and follower development. Leadership Quarterly, 16(3): 343-372.

Gardner W, Cogliser C, Davis K, and Dickens M (2011) Authentic leadership: A review of the literature and research agenda. Leadership Quarterly, 22(1): 1120-1145.

Gardner W, Fischer D \& Hunt J (2009) Emotional labor and leadership: A threat to authenticity? Leadership Quarterly, 20, 466-482.

Govern J and Marsch L (2001) Development and validation of the Situational SelfAwareness Scale. Consciousness and Cognition, 10(3): 366-378.

Grace D (2006) For business ethics. Australian Journal of Management, 31(2), 371-380.

Graen G and Uhl-Bien M (1995) Relationship-based approach to leadership:

Development of leader-member exchange (LMX) theory of leadership over 25 years: Applying a multi-level multi-domain perspective. Leadership Quarterly, 6(2): 219247.

Grant-Smith, D \& Colley L (2018) Of 'Strong'Leadership, Crisis Communication, and Pooper Scoopers: Change in the Queensland Public Service Under Newman. Australian Journal of Public Administration, 77(2), 236-252.

Gray S, Harymawan I \& Nowland J (2016) Political and government connections on corporate boards in Australia: Good for business?. Australian Journal of Management, 41(1), 3-26. 
Hackman J (2009) The perils of positivity. Journal of Organisational Behaviour, 30(2): 309319.

Hannah S, Lester P and Vogelgesang G (2005) Moral leadership: Explicating the moral component of authentic leadership. In: Gardner W, Avolio B and Walumbwa F (eds) Authentic leadership theory and practice: Origins, effects and development. Amsterdam, NL: Elsevier, pp. 43-81.

Hart D and Carlo G (2005). Moral development in adolescence. Journal of Research on Adolescence, 15(3): 223-233.

Holmes S \& Zimmer I (1994) The nature of the small firm: understanding the motivations of growth and non-growth oriented owners. Australian Journal of Management, 19(1), 97-120.

Hopkins M \& O’Neil D (2015) Authentic leadership: application to women leaders. Frontiers in Psychology, 6, 959.

Hsu M, Bhatt M, Adolphs R, Tranel D and Camerer C (2005) Neural systems responding to degrees of uncertainty in human decision-making. Science, 310(5754): 1680-1683.

$\mathrm{Hu}$ J and Liden R (2013) Relative leader-member exchange within team contexts: How and when social comparison impacts individual effectiveness. Personnel Psychology, 66(1): 127-172.

Ibarra H (2015) The authenticity paradox: Why feeling like a fake can be a sign of growth. Harvard Business Review, Jan-Feb, n.p.

Iszatt-White M and Kempster S (2018) Authentic leadership: Getting back to the roots of the 'root construct'?. International Journal of Management Reviews. Advanced online publication. 
Iszatt-White M, Whittle A, Gadelshina G \& Mueller F (2018) The 'Corbyn phenomenon': Media representations of authentic leadership and the discourse of ethics versus effectiveness. Journal of Business Ethics, 1-15.

Jones B (2016) An Auto-Ethnographic Study of a Black Female Pastor's Wilderness

Experience toward Authentic Leadership. Doctoral dissertation, Union Institute and University.

Joseph D and Newman D (2010) Emotional intelligence: an integrative meta-analysis and cascading model. Journal of Applied Psychology, 93(1): 54-78.

Lalor P (2018) Ball tampering: Sri Lanka captain Dinesh Chandimal charged with ball tampering. The Australian. June 17, 2018.

LeBrasseur R, Whissell R and Ojha A (2002) Organisational learning, transformational leadership and implementation of continuous quality improvement in Canadian hospitals. Australian Journal of Management, 27(2): 141-162.

Liu H, Cutcher L \& Grant D (2015) Doing authenticity: The gendered construction of authentic leadership. Gender, Work \& Organisation, 22(3), 237-255.

Kabalo P (2017) David Ben-Gurion's leadership as a “two-way interaction process”. Leadership, 13(3): 320-342.

Kellerman B (2012) The end of leadership. New York, NY: HarperCollins.

Kernis M and Goldman B (2006) A multicomponent conceptualisation of authenticity: Theory and research. Advances in Experimental Social Psychology, 38(1): 283-357.

Khilji S, Keilson B, Shakir F \& Shrestha B (2015) Self, follower, organisation and the context-a cross cultural view of authentic leadership. South Asian Journal of Global Business Research, 4(1), 2-26. 
Kiersch C and Byrne Z (2015) Is being authentic being fair? Multilevel examination of authentic leadership, justice, and employee outcomes. Journal of Leadership and Organisational Studies, 22(3): 292-303.

Ladkin D, Spiller C \& Craze G (2018) The journey of individuation: A Jungian alternative to the theory and practice of leading authentically. Leadership, online-first.

Law K, Wong C-S and Mobley W (1998) Toward a taxonomy of multidimensional constructs. Academy of Management Review, 23(4): 741-755.

Lawler J, and Ashman I (2012) Theorizing leadership authenticity: A Sartrean perspective. Leadership, 8(4): 327-344.

Learmonth M and Morrell K (2016) Is critical leadership studies 'critical'?. Leadership, 13(3): $257-271$

Liu H (2017) Reimagining ethical leadership as a relational, contextual and political practice. Leadership, 13(3): 343-367.

Locke E (2012) Construct validity vs. concept validity. Human Resource Management Review, 22(2): 146-148.

Loew L \& Wentworth D (2013) Leadership: The state of development programs: Researchbased industry perspective. Delray Beach, FL: Brandon Hall Group.

Luthans F and Avolio B (2003) Authentic leadership development. In Cameron K, Dutton J and Quinn R (eds) Positive organisational scholarship: Foundations of a new discipline. San Francisco: Berrett Koehler Publishers.

Luthans F and Youssef-Morgan C (2017) Psychological Capital: An evidence-based positive approach. Annual Review of Organisational Psychology and Organisational Behaviour, 4(1): 17.1-17.28. 
MacKenzie S, Podsakoff P and Jarvis C (2005) The problem of measurement model misspecification in behavioural and organisational research and some recommended solutions. Journal of Applied Psychology, 90(4): 710.

Mahoney L \& Thorne L (2005) Corporate social responsibility and long-term compensation: Evidence from Canada. Journal of Business Ethics, 57(3), 241-253.

Marsh I (1996) Business Ethics: Australian Problems and Cases. Australian Journal of Management, 21(1), 85-87.

McDowell J Huang Y and Caza A (2018) Does Identity Matter? An Investigation of the Effects of Authentic Leadership on Student-Athletes' Psychological Capital and Engagement. Journal of Sport Management, 32(3): 227-242.

McGregor C (2018) Shorten's leadership on the line - and that brings me no joy. Sydney Morning Herald. 27 July 2018.

Miller R \& Vaccaro A (2016) Queer student leaders of color: Leadership as authentic, collaborative, culturally competent. Journal of Student Affairs Research and Practice, 53(1), 39-50.

Neider L and Schriesheim C (2011) The Authentic Leadership Inventory (ALI): Development and empirical tests. Leadership Quarterly, 22(1): 1146-1164.

Newstead T, Macklin R, Dawkins S \& Martin A (2018) What is virtue? Advancing the conceptualisation of virtue to inform positive organisational inquiry. Academy of Management Perspectives, in-press.

Nyberg D and Sveningsson S (2014) Paradoxes of authentic leadership: Leader identity struggles. Leadership, 10(4): 437-455.

O’Neill M \& Liu Z (2016) Tail risk hedging for mutual funds using equity market state prices. Australian Journal of Management, 41(4), 687-698. 
Pekerti A \& Sendjaya S (2010) Exploring servant leadership across cultures: Comparative study in Australia and Indonesia. International Journal of Human Resource Management, 21(5), 754-780.

Podsakoff P, MacKenzie S and Podsakoff N (2016) Recommendations for Creating Better Concept Definitions in the Organisational, Behavioural, and Social Sciences. Organisational Research Methods, 19(2): 159-203.

Price T (2017) A “critical leadership ethics" approach to the Ethical Leadership construct. Leadership, in-press.

Procknow G, Rocco T \& Munn S (2017) (Dis) Ableing Notions of Authentic Leadership Through the Lens of Critical Disability Theory. Advances in Developing Human Resources, 19(4), 362-377.

Rangel A, Camerer C and Montague P (2008) A framework for studying the neurobiology of value-based decision making. Nature Reviews Neuroscience, 9(7): 545-556.

Rego P, Lopes M \& Simpson A (2017) The authentic-Machiavellian leadership grid: A typology of leadership styles. Journal of Leadership Studies, 11(2), 48-51.

Sendjaya S, Pekerti A, Härtel C, Hirst G \& Butarbutar I (2016) Are authentic leaders always moral? The role of Machiavellianism in the relationship between authentic leadership and morality. Journal of Business Ethics, 133(1), 125-139.

Sheehan C, De Cieri H, Cooper B and Brooks R (2016) The impact of HR political skill in the HRM and organisational performance relationship. Australian Journal of Management, 41(1): 161-181.

Steffens N, Mols F, Haslam S and Okimoto T (2016) True to what we stand for: Championing collective interests as a path to authentic leadership. Leadership Quarterly, 27(5): 726-744. 
Stewart D, Verbos A, Birmingham C, Black S and Gladstone J (2017) Being Native American in business: Culture, identity, and authentic leadership in modern American Indian enterprises. Leadership, 15(3): 549-570.

Suddaby R (2010) Editor's comments: Construct clarity in theories of management and organisation. Academy of Management Review, 35(3): 346-357.

The Ethics Centre (2018) Australia cricket: A matter of balance. The Ethics Centre. Report: October 2018.

Tice D and Wallace H (2003) The reflected self: Creating yourself as (you think) others see you. In: Leary M and Tangney J (eds) Handbook of self and identity. New York, NY: Guilford Press, pp. 91-105.

Toor S and Ofori G (2008) Leadership versus management: How they are different, and why. Leadership and Management in Engineering, 8(2): 61-71.

Trilling L (1971) Sincerity and authenticity. Cambridge, MA: Harvard University Press.

Walumbwa F, Avolio B, Gardner W, Wernsing T and Peterson S (2008) Authentic leadership: Development and validation of a theory-based measure. Journal of Management, 34(1): 89-126.

Wilson M (2014) Critical reflection on authentic leadership and school leader development from a virtue ethical perspective. Educational Review, 66(4), 482-496.

Wright T (2015) Distinguished scholar invited essay: Reflections on the role of character in business education and student leadership development. Journal of Leadership and Organisational Studies, 22(3): 253-264.

Yukl G (2013) Leadership in organisations. Albany, US: Prentice Hall, State University of New York.

Zaleznik A (2004) Managers and leaders: Are they different?. Harvard Business Review, Jan2004. 
Zhu W, Riggio R, Avolio B and Sosik J (2011) The effect of leadership on follower moral identity: Does transformational/ transactional style make a difference? Journal of Leadership and Organisational Studies, 18(2): 150-163. 
Table 1. Similarities in authentic leaders and authentic individuals.

\begin{tabular}{|c|c|}
\hline $\begin{array}{c}\text { Authentic leaders } \\
\text { (Walumbwa et al., 2008) }\end{array}$ & $\begin{array}{c}\text { Authentic individuals } \\
\text { (Kernis \& Goldman, 2006) }\end{array}$ \\
\hline $\begin{array}{l}\text { Self-awareness is the demonstrated } \\
\text { understanding of how one derives and generates } \\
\text { meaning, and how this impacts their own self- } \\
\text { concept. }\end{array}$ & $\begin{array}{l}\text { Awareness is the possessing and motivation to } \\
\text { increase, knowledge of and trust in self-relevant } \\
\text { cognitions, motives, feelings, and desires. }\end{array}$ \\
\hline $\begin{array}{l}\text { Balanced processing is objectively analysing } \\
\text { all relevant data before coming to a decision.; } \\
\text { soliciting views that challenge deeply held } \\
\text { positions. }\end{array}$ & $\begin{array}{l}\text { Unbiased processing is the processing of } \\
\text { information objectively with consideration to one's } \\
\text { positive/negative self-aspects, emotions, } \\
\text { information, and private knowledge; including non- } \\
\text { distortion or exaggeration of evaluative information. }\end{array}$ \\
\hline $\begin{array}{l}\text { Internalised moral perspectives is self- } \\
\text { regulation guided by internal moral standards } \\
\text { and values over group, organisational, or } \\
\text { societal influences. }\end{array}$ & $\begin{array}{l}\text { Behaviour is acting in accord with one's values, } \\
\text { preferences, and needs over acting for external } \\
\text { recognition or pain avoidance. }\end{array}$ \\
\hline $\begin{array}{l}\text { Relational transparency is the presentation of } \\
\text { one's true self to others through openness of } \\
\text { truthful thoughts and feelings. }\end{array}$ & $\begin{array}{l}\text { Relational authenticity involves valuing and } \\
\text { striving for openness, sincerity, and truthfulness in } \\
\text { one's close relationships }\end{array}$ \\
\hline
\end{tabular}


Figure 1. The four domains of the authentic leader-follower relationship

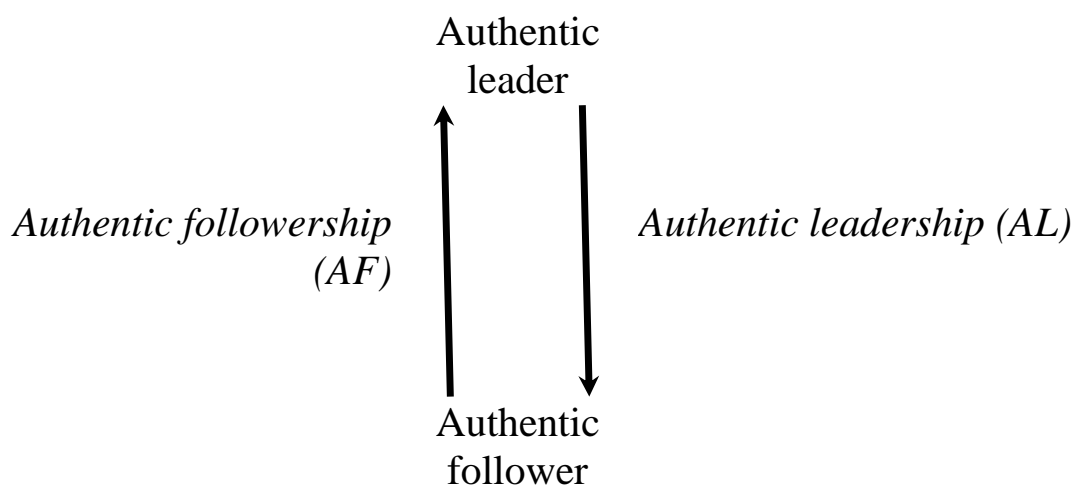


Figure 2. Differentiating the authentic leader and authentic follower.

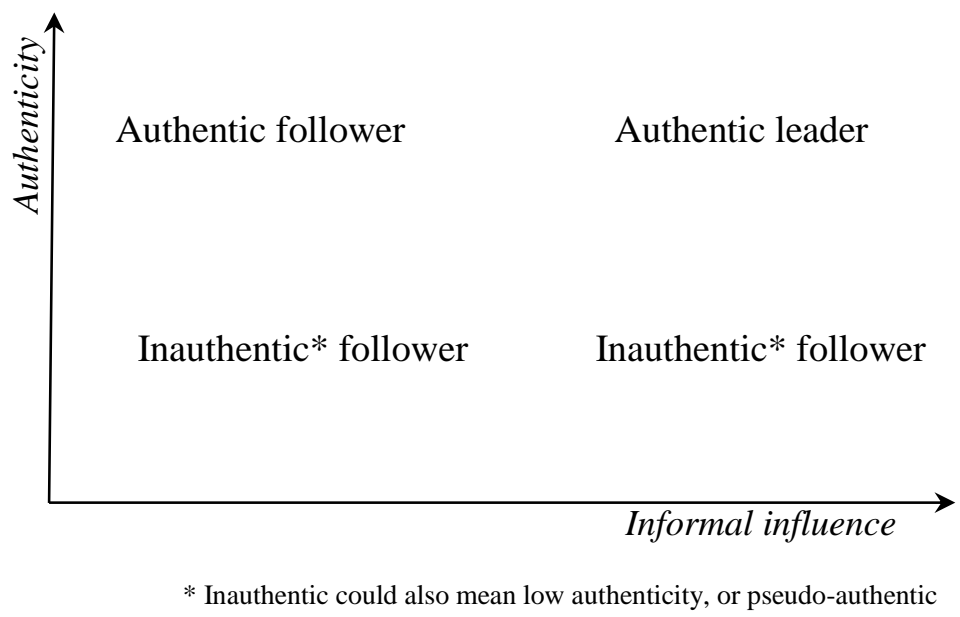

